\title{
EXHAUST EMISSIONS OF BIODIESEL AND ITS INFLUENTIAL PROPERTIES ON ENGINE PERFORMANCE CHARACTERISTICS
}

\author{
A. E. Gomaa ${ }^{1}$, H. H. Mohamed ${ }^{2}$, and M. D. Al-Aseebee ${ }^{3}$
}

\section{ABSTRACT}

Biodiesel was extracted from three different individual sources: waste frying oil, palm oil, and castor oil to find out if significant differences exist among biodiesel fuels within their thermo-physical properties and engine performance characteristics and the resulted exhaust emissions. The study investigated the effect of these biodiesels properties on engine performance characteristics, to determine the appropriate biodiesel source for best engine performance. The tested properties were: kinematic viscosity, density, flash point, heat value, and pour point. The tested exhaust emissions elements were: Oxygen, Sulfur dioxide, Carbon dioxide, Carbon monoxide, and Nitrogen oxides. Engine performance characteristics under evaluation were Brake power, Brake specific fuel consumption, and the Air fuel ratio.

\section{INTRODUCTION}

$\mathrm{U}$ sing biodiesel as a renewable fuel source is based on being an alternative liquid fuel produced by chemical reactions between vegetable oils or animal fats and a short-chain alcohol, such as methanol or ethanol in the presence of a catalyst. The main characteristics of biodiesel have been proved quite similar to mineral diesel. Efficient engine performance using a biodiesel fuel depends on the quality of the biodiesel properties. The differences in the chemical compositions and thermo-physical properties of biodiesels from different sources may bring about differences in engine performance characteristics. Biodiesel properties have a significant role for evaluating their adaptability for any engine operation. Few of the important biodiesel properties were determined and found in the comparable range with diesel fuel.

1- Emeritus Prof. of Ag. Eng.- Fac. of Ag. Saba Basha, Univ. of Alex. Egypt.

2- Lecturer of Ag. Eng.- Fac. of Ag. Saba Basha, Univ. of Alex. Egypt.

3- M.Sc. student, Fac. of Ag. Saba Basha, Univ. of Alex. Egypt. - Comer from Ministry of Agriculture, Iraq. 
Shrestha et al. (2005) defined Flash point of any fuel as the lowest temperature at which fuel vapor can be ignited by externally supplied ignition, in other words it signifies the temperature at which the fuel selfignites. Fernando et al. (2007) defined the cloud point as the temperature at which wax crystals first becomes visible when the fuel is cooled. Pour point is the temperature at which the amount of wax out of solution is sufficient to gel the fuel, thus it is the lowest temperature at which the fuel can flow. Rehman et al. (2009) defined cloud point as the temperature where crystal formation in the fuel starts and pour point as the temperature where fuel ceases to flow. They also mentioned that one of the major reasons hindering widespread use of biodiesel is its higher filter plugging temperature than regular diesel fuel. Cloud point and pour point temperature are shown to be well correlated with filter plugging point which primarily determines the operability of a diesel engine.

According to Rehman et al. (2009), the viscosity of a fuel is an important property which affects fuel atomization during the injection. High viscosity of plant oil was reported to be the main cause of injector chocking problem in C.I. engine. Sonune and Farkade (2012) reported that higher fuel viscosity results in poor atomization and larger fuel droplets followed by inadequate mixing of biodiesel droplets and air.

Buyukkaya (2010) pointed to the higher viscosity of biodiesel fuels, which may affect the engine brake effective power and engine torque especially at full-load conditions, increases the fuel momentum and consequently penetration depth in-cylinder. On the other hand, the higher viscosity and surface tension of biodiesel fuels prevent their sufficient breaking or disintegration during injection process.

Gumus et al. (2012) and Heywood (1988) justified that each biodiesel source may differ from another due to some factors such as air-fuel equivalence ratio, fuel properties, engine performance, chamber design, atomization rate, start of injection timing, injection pressure, engine load and speed which affect $\mathbf{C O}$ emissions which in fact expresses the lost chemical energy unused in the engine; it is the result of the incomplete combustion of the fuel; CO is highly produced from petroleum fuels, which contain no oxygen in their molecular structure. Dwivedi et al. (2014) stated that biodiesel has lower $\mathrm{C} / \mathrm{H}$ ratio due to its oxygenated 
nature and so the total amount of $\mathbf{C O}_{2}$ is found lower, when biodiesel is used. Kumar et al.(2014) stated that biodiesel injection affects the engine performance characteristics and exhaust emissions of the engine. The start of fuel injection can be influenced by changes in fuel properties like viscosity and in the changes in fuel injection timings. The start of injection is the point at which the injection line pressure matches with the nozzle opening pressure of the injector. The engine performance efficiency of the fuel in the engine can be computed by considering the energy required to produce $\mathrm{NOx}$ and the energy losses due to incomplete oxidation of $\mathrm{CO}$ to $\mathbf{C O}_{2}$ and unburnt hydrocarbon (UHC) to $\mathbf{C O}_{2}$ and $\mathrm{H}_{2} \mathrm{O}$. The increase in $\mathrm{NO}_{\mathbf{x}}$ emission may be related to the oxygen content of the biodiesel. The oxygenated biodiesel provides additional oxygen for NO $\mathbf{x}_{\mathbf{x}}$ formation. According to Aydin and Ilkilic (2010) the more completed engine performance, the higher engine performance temperature, which will cause higher $\mathbf{N O}_{\mathbf{x}}$ formation.

According to Peng (2015) Biodiesel fuels can be used in high-pressure engine performance engines, such as common rail injection engines in which high injection pressures allow rapid atomization and engine performance resulting in higher efficiencies and lower emissions. Gomaa et al. (2014) investigated tractor diesel engine performance when engine was fueled with three biodiesels separately; which were extracted from three different individual vegetable oils.

This study aims to investigate the differences that exist among three biodiesel samples obtained from: waste frying oil, palm oil and castor oil, and the possible impacts of biodiesels properties on the characteristics of the diesel engine performance. So the study was carried out to:

1) Determine the variation of the tested biodiesels thermo-physical properties and their resulted exhaust emissions and engine performance characteristics.

2) Determine whether significant differences exist among biodiesels within each property, within each element of their exhaust emissions and within each of their engine performance characteristics.

3) Investigate the effect of the tested biodiesels properties on engine performance characteristics, to obtain best engine performance. 


\section{MATERIALS AND METHOD}

\section{Preparation of biodiesel samples}

In the laboratory of Soil and Agricultural Engineering dept.-Faculty of Agriculture (Saba Basha); three different biodiesels were prepared from three different individual biosources, waste frying oil, palm oil, and castor oil, by transesterification process. They were tested as alternative fuels for tractor engine at the Testing and Research Station for Tractors and Agricultural Machinery, Alexandria.

\section{Density measurement:}

Density of each pure biodiesel was measured in the laboratory of Soil and Agricultural Engineering dept.- Faculty of Agriculture (Saba Basha) according to the standard steps and replications to determine the mass of a hypothetical volume of $20 \mathrm{ml}$ biodiesel :

$$
\text { Density }=\frac{\text { Biodiesel mass }}{20} \quad\left(\frac{\mathbf{g m}}{\mathbf{c m}^{3}}\right) \text { or }\left(\frac{\mathbf{k g}}{1}\right)
$$

The whole steps were repeated each time temperature was raised $20{ }^{\circ} \mathrm{C}$ until $100^{\circ} \mathrm{C}$.

\section{Dynamic viscosity measurement:}

The variation of the prepared biodiesels viscosities with raising temperature, were measured at the SOUTH REFINERIES - MINISTRY OF OIL - REPUBLIC OF IRAQ. Biodiesel viscosity was determined by using a viscometer, to measure the time of both biodiesel and distilled water flow through a definite distance in a tube of glass. The following equation was used:

$$
\frac{\eta_{1}}{\eta_{2}}=\frac{d_{1} \cdot t_{1}}{d_{2} \cdot t_{2}}
$$

Where, $t_{1}$ : measured flow time of the unknown biodiesel viscosity - $\mathbf{s}$.

$t_{2}$ : flow time of water $-\mathbf{s}$.

$\eta_{1}$ : unknown biodiesel viscosity

$\eta_{2}$ : Viscosity of water $0.891 \mathrm{ml}$ Pa.s, or 0.01 poise.

$\mathrm{d}_{1}$ : Biodiesel density - $\mathbf{g m} / \mathbf{c m}^{\mathbf{3}}$

$\mathrm{d}_{2}$ : density of water $-1 \mathbf{g m} / \mathbf{c m}^{\mathbf{3}}$

Kinematic viscosity $\left(\mathrm{mm}^{2} / \mathbf{s}\right)$ was then calculated as the quotient of the dynamic viscosity (ml Pa.s) and density (kg/l):

Kinematic viscosity $\left(\mathrm{mm}^{2} / \mathrm{s}\right)=\frac{\text { Dynamic viscosity }(\mathrm{ml} \mathrm{Pa.s})}{\text { Density }(\mathrm{kg} / \mathrm{l})}$ 
Measurements of the rest of the biodiesel properties were accomplished in Misr Petroleum Co. laboratory as displayed in Table (4).

The analysis of variance ( ANOVA) was applied to determine whether significant differences in their operational properties exist among biodiesel samples obtained from three different individual sources of vegetable oil, FO, PAO, and CAO. Exhaust emissions and thermophysical biodiesel properties(or operational properties) and their related engine performance characteristics; they all were subject to ANOVA of two - factor with replication, except flashpoint, heat value, and pour point which were subject to ANOVA of single factor.

Based on all of the above applied ANOVA the deduced judgement is based on the following principle: The absence of any significant differences among the tested biodiesels within any property can justify their common graphical trend within any engine performance characteristic BP, BSFC, and AFR; and vice versa.

\section{Engine torque and power measurements:}

A hydraulic brake stationary dynamometer $90 \mathrm{~kW}$ was hooked to $67 \mathrm{~kW}$ tractor to measure both torque and rpm exerted on the tractor power take off shaft (PTO) at different loads when operating the tractor engine on biodiesel as shown in Fig. (1).

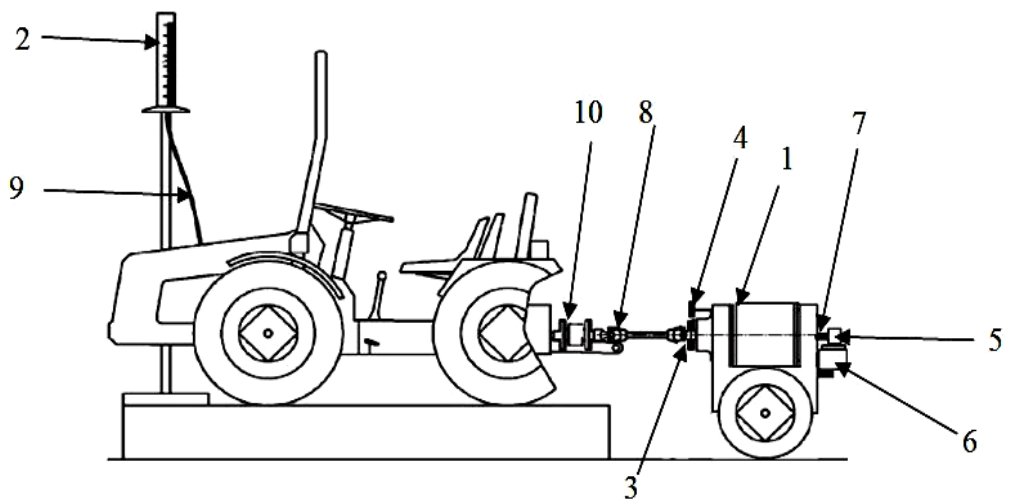

1-Hydraulic brake dynamometer

3-RPM toothed gear

5-Torque arm lever

7-Rotating drum shaft

9-Hose to injection pump
2-Fuel graduated cylinder

4-RPM magnetic core

6-Strain gage load cell

8-Tractor P.T.O shaft

10-Coupling connection

Fig.(1): Schematic view of the engine test arrangement. 
Technical specifications of the tractor and the hydraulic brake stationary dynamometer are given in Table (1):

Table (1) Technical specifications of the tractor and dynamometer

\begin{tabular}{|l|l|}
\hline Model & Kubota $\mathrm{M}_{1}-100 \mathrm{~S}-\mathrm{DT}$ \\
\hline Type of engine & $\begin{array}{l}\text { Four stroke, indirect injection } \\
\text {,Turbocharged, liquid cooled diesel }\end{array}$ \\
\hline Engine power, $\mathrm{kW}(\mathrm{HP})$ & $73.6(100)$ \\
\hline Rated Engine speed, rpm & 2600 \\
\hline Compression ratio & $21.8: 1$ \\
\hline Number of cylinders & 4-cylinder \\
\hline Bore * stroke, mm & $100 \times 120 \mathrm{~mm}$ \\
\hline \multicolumn{2}{|l|}{ Technical specifications of the hooked hydraulic brake stationary } \\
\hline \multicolumn{2}{|l|}{ dynamometer. } \\
\hline Model & NEB600 \\
\hline Serial number & CD6190C5 \\
\hline \multirow{2}{*}{ Range } & $300 \mathrm{~kW}$ at 540rpm \\
\cline { 2 - 2 } Capacity of torque & $600 \mathrm{~kW}$ at $1000 \mathrm{rpm}$ \\
\hline
\end{tabular}

A daytronic data PAC model 10k4 was used to record data measured by the torque cell sensor and the magnetic pick-up frequency sensor as shown in Fig (2). These two sensors are engaged to the AW dynamometer; The sensing torque cell has a full whinstone bridge of strain gage for recording the torque applied to P.T.O. during test; while a magnetic pick-up frequency sensor consists of a toothed wheel, (60 teeth), coil, and iron core was used to record the P.T.O shaft rpm, as the toothed wheel rotates, the magnetic field of the magnetized source is detected, and displayed as RPM.

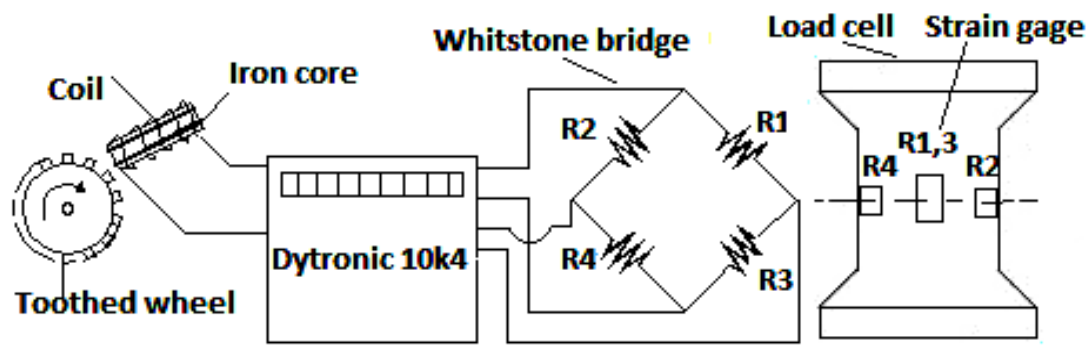

Fig. (2) Daytronic and AW sensors wiring diagram. 
The diesel engine gas emissions were measured by a gas analyzer. This gas analyzer consists of electrochemical sensors, and infrared flue gas analyzers. The temperature and the gas emissions concentrations $\left(\mathrm{CO}_{2}, \mathrm{CO}, \mathrm{NO}\right.$, $\mathbf{N O}_{\mathbf{x}}, \mathbf{O}_{2}$, and $\mathbf{S O}_{2}$ ) elements were detected by independent electrochemical sensor. Fig.(3) illustrates the connection of the gas

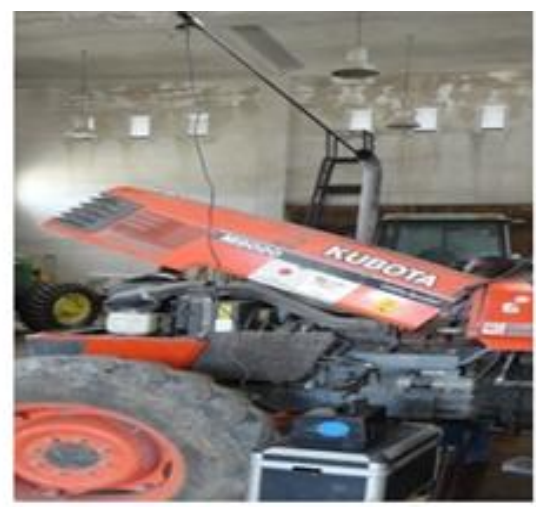
analyzer to the tractor exhaust pipe during the test.

The tractor was kept running for one hour before start the measurements to warm up all parts and liquids to reach the best working temperature. At the same time and before each measurement for each fuel type, the whole system was running for $10 \mathrm{~min}$ at full throttle. Every measurement of torque and rotational speed of PTO was recorded at tractor full throttle. During the experiments, the time required for consuming $100 \mathrm{~cm} 3$ of each fuel was also recorded; the first measurement was carried out at no load, then at a standard PTO speed of $540 \mathrm{rpm}$, and finally at maximum load. For every subsequent measurement, the load on the AW hydraulic brake was increased in order to decrease the rotational speed of the PTO. All engine settings (throttle, cooling...) remained unchanged during the whole experiment for each particular fuel type. When testing a new fuel it was made sure that, the previously tested fuel was completely removed from the pipelines and filter system by running the engine on the new fuel for $10 \mathrm{~min}$ at full throttle before doing any new measurements.

\section{Engine Performance Characteristics:}

\section{PTO Torque and Power:}

Both PTO torque in N.m and rotational speed in rpm, were measured in the lab using the AW hydraulic brake stationary dynamometer for tractor power take off shaft calculation, , at different PTO speed, using the following equation.

$$
P=2 \pi n \tau / c
$$

$\mathrm{kW}$

Where: 


$\begin{array}{lll}\mathrm{P} & \text { Power take-off shaft P.T.O } & \mathrm{kW} \\ \mathrm{n} & \text { Measured rotational speed of P.T.O } & \mathrm{rpm} \\ \tau & \text { Measured torque of P.T.O in } & \text { N.m } \\ \mathrm{c} & \text { constant, equals } 60000 & \end{array}$

\section{Engine Brake Power BP:}

According to KUBOTA tractor technical data, PTO power is $88.9 \%$ of the engine BP. For a used tractor the PTO power was considered as $88 \%$ of the engine BP; and the ratio between the engine and PTO shaft speeds $(\mathrm{rpm})$ is $(2205 / 540)$ or $4.0833: 1$.

$$
B P=\frac{\text { PTO power }}{0.88}
$$

\section{Fuel Consumption:}

The volume of fuel consumption $\left(\mathrm{cm}^{3}\right)$ was measured during each test run at no load, at the standard PTO speed, and at full load. Consumption time for each test was also measured and the volumetric fuel consumption rate was calculated for each load as follows:

$$
V F C=(V * 3600) /(t * 1000) \quad l / h
$$

Where:

VFC: Volumetric fuel consumption rate, $1 . \mathrm{h}^{-1}$

$\mathrm{V}$ : volume of consumed fuel in glass bulb, $\mathrm{cm}^{3}$

$\mathrm{t}$ :Time of running the test, $\mathrm{s}$

\section{Brake thermal efficiency BTE:}

This parameter is obtained by dividing the effective power from the engine by the amount of energy given to the engine.

$$
B T E=\frac{B P \times 3600}{V F C \times \rho_{f} \times H V}
$$

Where:

$\mathrm{BP}=$ Brake power, $\mathrm{kW}$

$\rho_{f}=$ density of the tested fuel, $\mathrm{kg} / \mathrm{l}$

VFC $=$ volumetric Fuel consumption rate, $1 / \mathrm{h}$

$\mathrm{HV}=$ heat value of the tested fuel, $\mathrm{kJ} / \mathrm{kg}$.

\section{Brake Specific Fuel Consumption BSFC:}

BSFC is the quotient of the fuel consumption rate $(1 / h)$ and the corresponding $\mathrm{BP}(\mathrm{kW})$ at the same loading conditions represented by the different levels of engine speed (rpm) starting from 408.33 to 2858.31(100 to 700 PTO rpm). 


$$
B S F C=\frac{V F C}{B P} \quad l /(k W . h)
$$

\section{Brake Mean Effective Pressure BMEP:}

BMEP is a useful term which can be obtained if the standard expression for computing indicated power IP is applied to brake power BP instead of IP. So BP in $\mathrm{kW}$ can be expressed as follows:

$$
B P=\frac{B M E P \times L \times A \times n \times N}{60 \times 2}
$$

Where, BMEP: Brake Mean Effective Pressure, kPa.

L: Piston displacement, $m$.

A: Piston cross-sectional area, $\mathrm{m} 2$.

$\mathrm{N}$ : Engine rotation speed, rpm.

$\mathrm{n}$ : Number of engine cylinders,

2: Constant associated with a 4 stroke engine.

60: Constant for unit conversion, s.

BMEP gives an indication of the engine state at a certain loading level, which expresses the output per piston displacement. As BMEP increases, the engine develops greater power, where its BMEP changes in direct proportion with load as follows:

$$
B M E P=\frac{B P \times 120}{L \times A \times n \times N} \ldots \ldots \ldots
$$

\section{Air Fuel Ratio AFR:}

AFR is defined as the ratio of the mass of air to the mass of fuel in the engine. Hence, the following steps had to be measured:

1- Air mass flow rate.

2- Fuel mass flow rate from the system measurement equipment.

3- The quotient of step 1 by step 2 is the AFR. Volumetric efficiency $\boldsymbol{\eta}_{\mathbf{v}}$ is defined as the ratio of air volume input / minute, $\mathbf{v a}$, measured at the inlet air conditions, to the number of cylinder swept volume / minute, vs:

$$
\eta_{v}=\frac{v_{a}}{v_{s}}
$$

The $\boldsymbol{\eta}_{\mathbf{v}}$ of the KUBOTA tractor supercharged engine, could be determined at any operating point (engine speed) As later shown and 
explained from Fig.(15), from which the actual air volume flow rate, va $\left(\mathrm{m}^{3} /(\mathrm{min} \cdot \mathrm{cyl})\right)$ could also be determined per one single cylinder from equation (8) as follows:

$$
v_{a}=\eta_{v} \times v_{s}
$$

Where,

$$
\begin{aligned}
& \mathrm{v}_{\mathrm{s}}=\left(\frac{\text { number of suction strokes }}{\min \cdot \mathrm{cyl}}\right) \times \text { piston surface area } \times \text { displacement } \\
& \mathrm{v}_{\mathrm{s}}=\left(\frac{\text { Engine revs. }}{\min \cdot 2 \cdot \mathrm{cyl}}\right) \times \frac{\mathrm{cm}^{2} \cdot \mathbf{c m}}{10^{6}}
\end{aligned}
$$

Air mass flow rate $\left(\frac{\mathrm{kg}_{\mathrm{ma}}}{\min \cdot \mathrm{cyl}}\right)=\mathrm{v}_{\mathrm{a}}\left(\frac{\mathrm{m}^{3}}{\min \cdot \mathrm{cyl}}\right) \times$ air density $\left(\frac{\mathrm{kg}_{\mathrm{ma}}}{\mathrm{m}^{3}}\right)$..(10)

An average air density is considered of $1.205 \mathrm{~kg} / \mathrm{m}^{3}$ at sea level $(\mathrm{p}=101.3$ $\mathrm{kP}_{\mathrm{a}}, \mathrm{t}=20^{\circ} \mathrm{C}$ ). Table (1) shows the measured density data for all tested fuels in $\left(\mathrm{kg}_{\mathrm{m}} / \mathrm{l}\right)$. The measured fuel consumption rate for all tested fuels was divided by 4 cylinders to determine the fuel consumption rate $\mathrm{v}_{\mathrm{f}}$ per one single cylinder in (1/min.cyl). Then the mass flow rate of all tested fuels is determined as follows:

$$
\begin{aligned}
& \text { Fuel mass flow rate }\left(\frac{\mathrm{kg}_{\mathrm{mf}}}{\min \cdot \mathrm{cyl}}\right)=\mathrm{v}_{\mathrm{f}}\left(\frac{\mathrm{l}}{\min \cdot \mathrm{cyl}}\right) \times \text { fuel density }\left(\frac{\mathrm{kg}_{\mathrm{mf}}}{\mathrm{l}}\right) \ldots(\mathbf{1 1}) \\
& \mathrm{AFR}=\text { Air mass flow rate }\left(\frac{\mathrm{kg}_{\mathrm{ma}}}{\min \cdot \mathrm{cyl}}\right) / \text { Fuel mass flow rate }\left(\frac{\mathrm{kg}_{\mathrm{mf}}}{\min \cdot \mathrm{cyl}}\right) \ldots \ldots \ldots . . .
\end{aligned}
$$

The detailed description of test procedure concerning the variation of AFR with engine speed is presented in the next section: Results and Discussion.

\section{RESULTS AND DISCUSSION}

\section{1- Biodiesel properties}

\section{1 - Operational properties}

Operational properties of biodiesel samples considered under the present study are: density, kinematic viscosity, Flashpoint, Heat value, and Pour point.

1.1.1-Density and Kinematic viscosity (properties subject to two factor with rep. ANOVA) :

Figs (4\&5) illustrate the variation of biodiesels Density and Kinematic viscosity resp. with temperature levels. Density trends for all tested biodiesel fuels are common and close together; this behavior is 
confirmed by their related ANOVA shown in Table (2) which confirmed the absence of significant density differences among Biodiesel fuels; which in turn can participate in the resulted common Biodiesel fuels trends and the absence of significant differences between them within all engine performance characteristic BP, BSFC, and AFR.

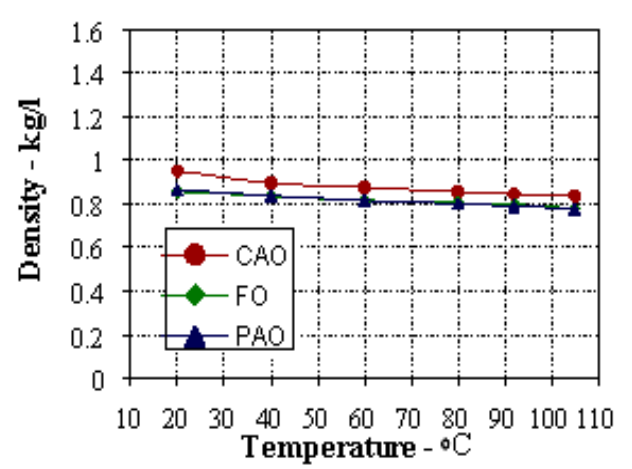

Fig.(4): Variation of density with temperature of biodiesel from three different sources.

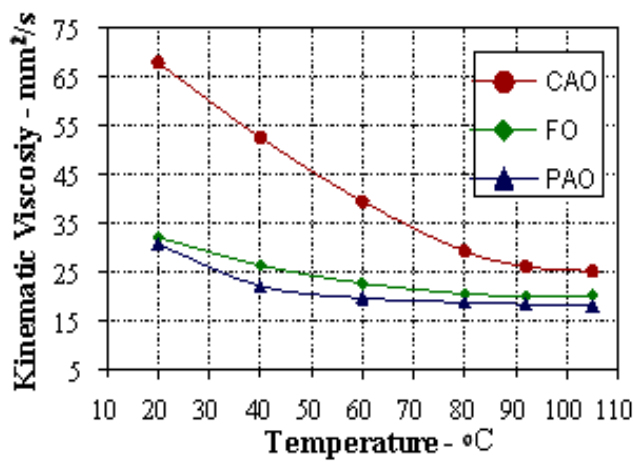

Fig.(5): Variation of kinematic viscosity with temperature of biodiesel from three different sources.

Kinematic viscosity trends of the same tested biodiesels were not totally in harmony; while biodiesel trends originated from Palm and Fried oil were adjacent, Castor oil was quite higher than them. These mixed viscosity trends of the tested biodiesels resulted in significant Kinematic viscosity differences among biodiesel fuels as confirmed by their ANOVA in Table (3). But this case of existing viscosity significant differences didn't reflect any particular difference in the complete common sources behavior shown by the engine performance characteristic BP, BSFC, and AFR (Figs(11,12,\&13)), which also didn't contain any significant differences among biodiesel fuels.

Table (2): Analysis of Density Variance - kg/l.

\begin{tabular}{|l|c|c|c|c|c|c|}
\hline Source of Variation & SS & df & MS & F & P-value & F crit \\
\hline Temperature Levels & 0.05243 & 5 & 0.010486 & 0.375138 & 0.862379 & 2.477169 \\
\hline Among Biodiesel fuels & 0.045923 & 2 & 0.022961 & 0.821455 & 0.447865 & 3.259446 \\
\hline Interaction & 0.002355 & 10 & 0.000236 & 0.008426 & 1 & 2.106054 \\
\hline Within & 1.006277 & 36 & 0.027952 & & & \\
\hline Total & 1.106984 & 53 & & & & \\
\hline
\end{tabular}


Table (3): Analysis of Kinematic Viscosity Variance $-\mathrm{mm}^{2} / \mathrm{s}$.

\begin{tabular}{|l|c|c|c|c|c|r|}
\hline Source of Variation & SS & df & MS & F & P-value & F crit \\
\hline Temperature Levels & 3500.567 & 5 & 700.1135 & 18.13456 & $5.8 \mathrm{E}-09$ & 2.477169 \\
\hline Among Biodiesel fuels & 3757.307 & 2 & 1878.653 & 48.66146 & $5.82 \mathrm{E}-11$ & 3.259446 \\
\hline Interaction & 1574.31 & 10 & 157.431 & 4.077826 & 0.000847 & 2.106054 \\
\hline Within & 1389.837 & 36 & 38.6066 & & & \\
\hline Total & 10222.02 & 53 & & & & \\
\hline
\end{tabular}

1.1.2 - Flashpoint, Calorific or Heat value, and pour point (properties subject to single factor ANOVA):

Table (4) displays the average values of biodiesels operational properties subject to single factor ANOVA; which were measured at Misr Petroleum Co. laboratory. ANOVA was determined for each property and presented by Tables (5, 6 and 7). Referring to Tables (5\&6), no significant differences were found among biodiesel fuels neither in their flashpoint nor in their heat value. In spite of the pour point similar average measured values in both of PAO \& CAO, pour point ANOVA in Table (6) indicated significant differences between all biodiesel fuels due to the far FO value.

Table (4): Av. values of biodiesels operational properties subject to single factor ANOVA.

\begin{tabular}{l|c|c|c}
\hline \multicolumn{1}{c|}{ Property } & FO & PaO & CaO \\
\hline Flash point ${ }^{\circ} \mathrm{C}$ & 140 & 185 & 170 \\
\hline Pour point ${ }^{\circ} \mathrm{C}$ & -6 & 12 & 12 \\
\hline Calorific value $(\mathrm{MJ} / \mathrm{kg})$ & 42.3 & 42.3 & 42.5 \\
\hline Ash content $(\%$ by weight) & Nil & Nil & Nil \\
\hline
\end{tabular}

Among all of the above analyzed biodiesels operational properties, only Kinematic viscosity and Pour point showed significant differences among biodiesel fuels; while the effect within the majority or the rest of the tested properties didn't result any significant differences among biodiesel fuels, and this can strongly participate in supporting the common graphical behavior of all of the evaluated engine performance characteristics BP, BSFC, and AFR, (Figs(11,12,\&13)), which also didn't contain any significant differences among biodiesel fuels.

Table (5) Analysis of Flashpoint variance ${ }^{\circ} \mathrm{C}$

\begin{tabular}{|l|c|c|c|c|c|c|}
\hline Source of Variation & SS & df & MS & F & P-value & F crit \\
\hline Among Biodiesel fuels & 3150 & 2 & 1575 & 1.427924 & 0.311002 & 5.143253 \\
\hline Within Biodiesel fuels & 6618 & 6 & 1103 & & & \\
\hline Total & 9768 & 8 & & & & \\
\hline
\end{tabular}


Table (6) Analysis of Heat value variance $M J / k g$

\begin{tabular}{|l|c|c|c|c|c|c|}
\hline Source of Variation & SS & df & MS & F & P-value & F crit \\
\hline Among Biodiesel fuels & 0.08 & 2 & 0.04 & 0.000557 & 0.999443 & 5.143253 \\
\hline Within Biodiesel fuels & 430.7864 & 6 & 71.79773 & & & \\
\hline Total & 430.8664 & $\mathbf{8}$ & & & & \\
\hline
\end{tabular}

Table (7) Analysis of pour point variance ${ }^{\circ} \mathrm{C}$

\begin{tabular}{|l|l|l|l|l|l|l|}
\hline Source of Variation & SS & df & MS & F & P-value & F crit \\
\hline Among Biodiesel fuels & 648 & 2 & 324 & 75 & $5.68958 \mathrm{E}-05$ & 5.143253 \\
\hline Within Biodiesel fuels & 25.92 & 6 & 4.32 & & & \\
\hline Total & 673.92 & 8 & & & & \\
\hline
\end{tabular}

\subsection{Exhaust emissions}

\subsection{1 - $\mathrm{O}_{2}$ Emission}

$\mathrm{O}_{2}$ emission from tractor diesel engine is shown in Fig. (6); $\mathrm{O}_{2}$ emission was almost in direct proportion with Engine Rotation Speed and of common trend for all tested biodiesels; it is observed that FO, CAO, and PAO contain higher amounts of $\mathrm{O}_{2}$ than pure diesel at any level of the Engine Rotation Speed which lead to greater oxidation than diesel fuel. This high amount of $\mathrm{O}_{2}$ in biodiesels helps to contribute in higher engine performance; the exceeded $\mathrm{O}_{2}$ is swept out of the engine cylinder through exhaust process. The common trend of the tested biodiesels is justified by the absence of significant $\mathrm{O}_{2}$ emission differences among biodiesel fuels as confirmed by their related ANOVA in Table (8).

\subsection{2 - $\mathrm{SO}_{2}$ Emission}

Fig.(7) showed that the concentration of $\mathrm{SO} 2$ in the engine exhaust is almost nihilistic for all tested biodiesels; while it was reduced from over $20 \mathrm{ppm}$ at no load to almost $4 \mathrm{ppm}$ for diesel fuel at maximum load.

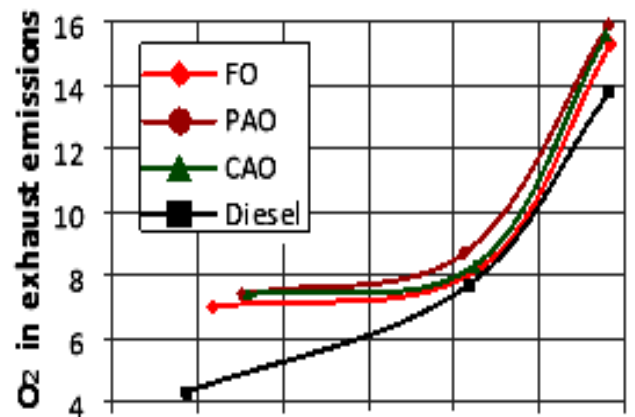

¿ 1400160018002000220024002600

¿e Engine Rotation Speed - rpm

Fig.(6): Variation of $\mathrm{O}_{2}$ emission with load increase for all tested biofuels \& diesel fuel

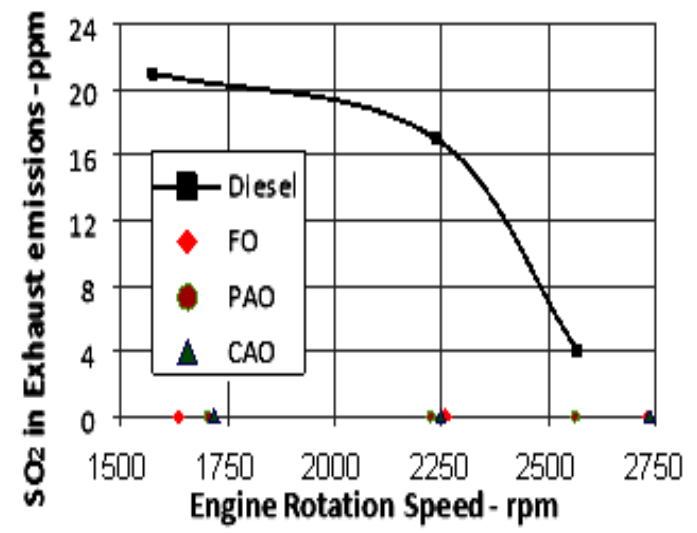

Fig. (7): Variation of $\mathrm{SO}_{2}$ emission with load increase for diesel fuel \& zero $\mathrm{SO}_{2}$ emission for all tested biofuels 


\subsection{3 - $\mathrm{CO} \& \mathrm{CO}_{2}$ Emission}

Figs.(8\&9) present the variation in $\mathbf{C O}_{2}$ and $\mathbf{C O}$ emission resp. with load increase for all tested biodiesels and diesel fuel, their content in diesel fuel always exceeded which of biodiesels especially at low loading levels. All tested biodiesels were subjected to a common trend, this is due to the absence of significant $\mathrm{CO}_{2}$ emission differences among biodiesel fuels as confirmed by their ANOVA in Table (9); biodiesels trends of their $\mathbf{C O}$ emission were not in complete harmony which are justified by the presence of their significant differences among biodiesel fuels as shown by their ANOVA in Table (10). This is discussed and justified in the above introduction by Gumus et al. (2012) and Heywood (1988).

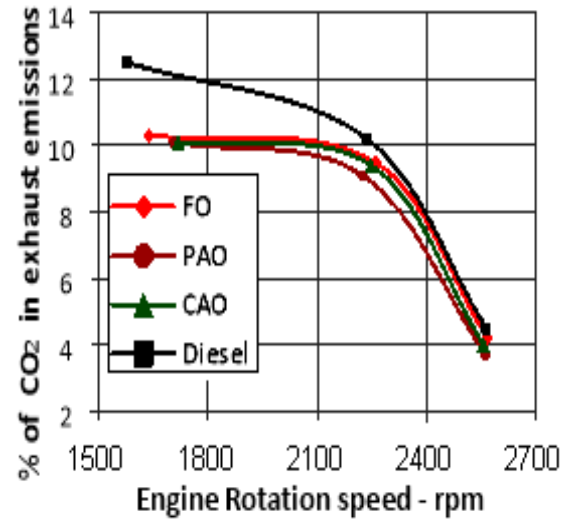

Fig. (8)Variation of $\mathrm{CO}_{2}$ emission with load increase for all tested biofuels \& diesel fuel

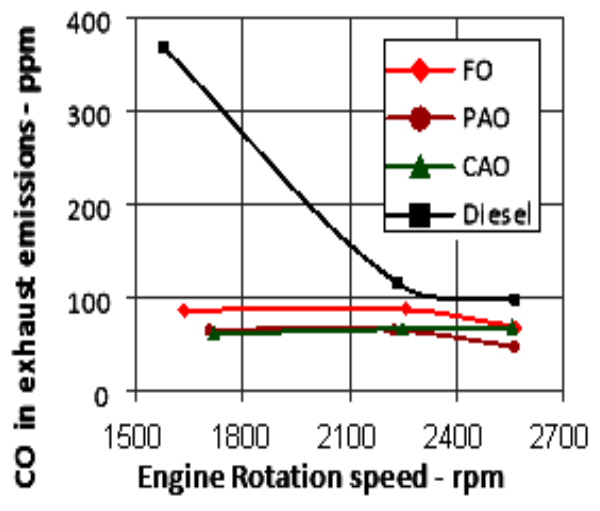

Fig.(9)Variation of $\mathrm{CO}$ emission with load increase for all tested blofuels \& diesel fuel

\subsection{4 - NO $\mathrm{N}_{\mathrm{x}}$ Emission}

Fig. (10) shows the variation of NOx emissions at different loads expressed by engine speed for biodiesels and diesel fuel. Nitrogen oxides (NOx) in the exhaust emissions contain nitric oxide (NO) and nitrogen dioxide (NO2). It is quite high with biodiesel compared to diesel fuel at load increase. All tested biodiesels had a common
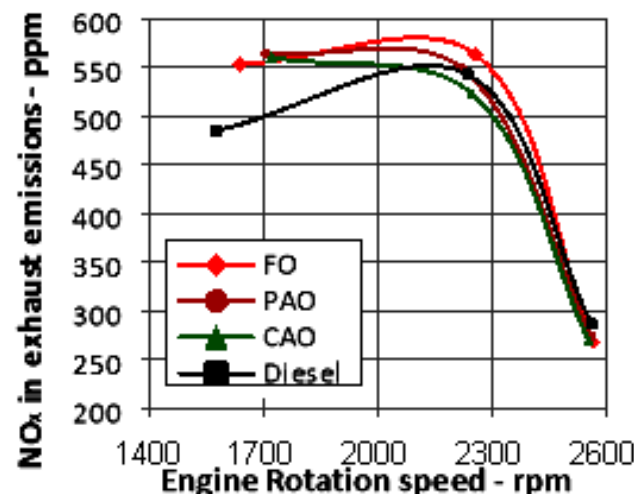

Fig.(10)Variation of $\mathrm{NO}_{x}$ emission with load increase for all tested biofuels \& diesel fuel 
trend which is justified by the absence of significant $\mathrm{NO}_{\mathrm{x}}$ emission differences among biodiesel fuels as confirmed by their ANOVA in Table (11).

Table (8) Analysis of $\mathrm{O} 2$ variance in tractor exhaust emissions - \%.

\begin{tabular}{|c|c|c|c|c|c|c|}
\hline Source of Variation & SS & $\mathrm{df}$ & MS & $\mathrm{F}$ & P-value & F crit \\
\hline Engine Speed Levels & 367.7067 & 2 & 183.8533 & 37.58586 & $3.75 \mathrm{E}-07$ & 3.554557 \\
\hline Among Biodiesel fuels & 1.126667 & 2 & 0.563333 & 0.115164 & 0.891871 & 3.554557 \\
\hline Interaction & 0.153333 & 4 & 0.038333 & 0.007837 & 0.999865 & 2.927744 \\
\hline Within & 88.048 & 18 & 4.891556 & & & \\
\hline Total & 457.0347 & 26 & & & & \\
\hline
\end{tabular}

Table (9) Analysis of CO2 variance in tractor exhaust emissions - \%.

\begin{tabular}{|l|c|c|c|c|c|c|c|}
\hline Source of Variation & & SS & df & MS & F & P-value & F crit \\
\hline Engine Speed Levels & 203.8067 & 2 & 101.9033 & 37.04917 & $4.16 \mathrm{E}-07$ & 3.554557 \\
\hline Among Biodiesel fuels & 0.606667 & 2 & 0.303333 & 0.110283 & 0.896181 & 3.554557 \\
\hline Interaction & 0.113333 & 4 & 0.028333 & 0.010301 & 0.999768 & 2.927744 \\
\hline Within & 49.5088 & 18 & 2.750489 & & & \\
\hline Total & 254.0355 & 26 & & & & \\
\hline
\end{tabular}

Table (10) Analysis of CO variance in tractor exhaust emissions - ppm

\begin{tabular}{|l|c|c|c|c|c|c|c|}
\hline Source of Variation & & SS & df & MS & F & P-value & F crit \\
\hline Engine Speed Levels & 700.6667 & 2 & 350.3333 & 1.784017 & 0.196407 & 3.554557 \\
\hline Among Biodiesel fuels & 2178.667 & 2 & 1089.333 & 5.547257 & 0.013279 & 3.554557 \\
\hline Interaction & 711.3333 & 4 & 177.8333 & 0.905588 & 0.481516 & 2.927744 \\
\hline Within & 3534.72 & 18 & 196.3733 & & & \\
\hline Total & 7125.387 & 26 & & & & \\
\hline
\end{tabular}

Table(11) Analysis of NOx variance in tractor exhaust emissions - ppm.

\begin{tabular}{|c|c|c|c|c|c|c|}
\hline Source of Variation & SS & df & MS & $\mathrm{F}$ & P-value & F crit \\
\hline Engine Speed Levels & 472402.7 & 2 & 236201.3 & 26.26541 & $4.59 \mathrm{E}-06$ & 3.554557 \\
\hline Among Biodiesel fuels & 640.6667 & 2 & 320.3333 & 0.035621 & 0.965074 & 3.554557 \\
\hline Interaction & 2005.333 & 4 & 501.3333 & 0.055748 & 0.993688 & 2.927744 \\
\hline Within & 161871.6 & 18 & 8992.867 & & & \\
\hline Total & 636920.3 & 26 & & & & \\
\hline
\end{tabular}

\section{Engine performance characteristics}

Since some of the engine performance characteristics are functions of, or implied in some others having their same trends and indications. We'll just discuss BP, BSFC, and AFR to express engine performance characteristics as affected by the above discussed biodiesel properties (Full evaluation of engine performance characteristics was accomplished by Gomaa et al. (2014)): 


\section{Brake Power (BP)}

In Fig.(11) the Brake Power increases with the increase of engine speed due to mass increase of burning fuel; the highest power values were obtained at 1900-2000 rpm engine speed. Conventional diesel fuel was of the highest output power $(53 \mathrm{~kW})$ because of its higher heat value than those of the tested biodiesels; power levels obtained from the tested biodiesel fuels were close to each other (around $45 \mathrm{~kW}$ ). The higher values of viscosity and density of biodiesels can partially explain this result as above explained by Buyukkaya (2010). The common BP trends of the tested biodiesels explain the absence of significant BP differences among biodiesel fuels as shown by their ANOVA in Table (12).

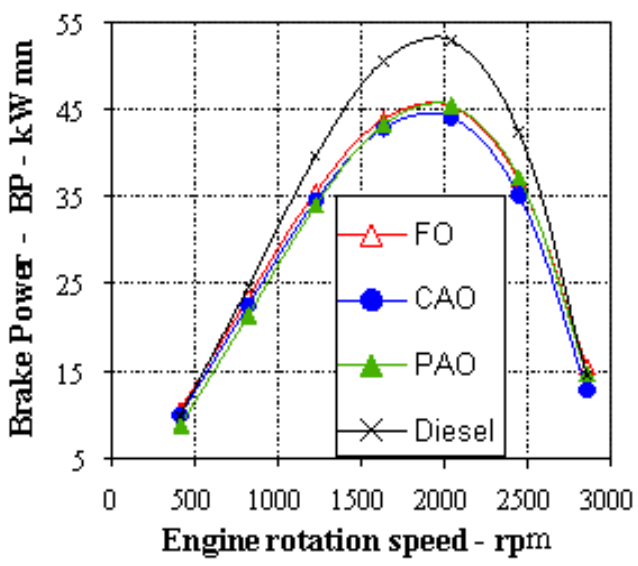

Fig.(11): Variation of Engine Brake Power $B P$ with engine speed.

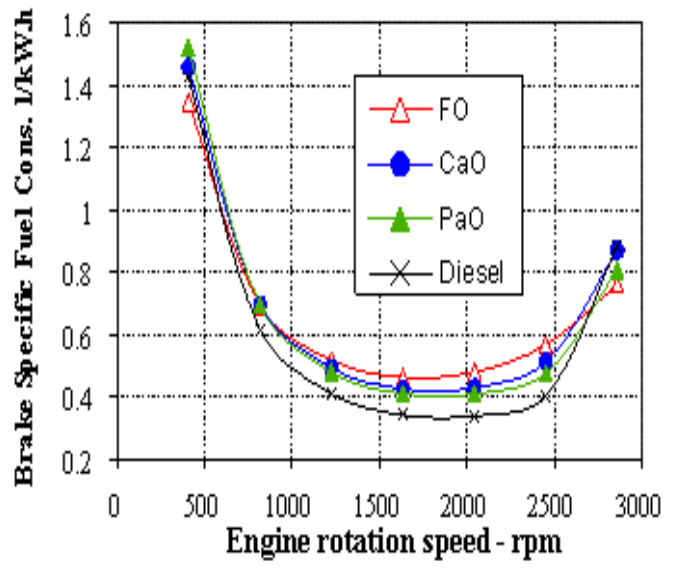

Fig.(12) Brake Specific Fuel Consumption BSFC variation with engine rotation speed, for all tested fuels.

Table (12) Analysis of Engine Brake Power variance - kW

\begin{tabular}{|l|c|c|c|c|c|c|}
\hline Source of Variation & SS & df & MS & F & P-value & F crit \\
\hline Engine Speed Levels & 10571.91 & 6 & 1761.985 & 42.64158 & $2.58 \mathrm{E}-16$ & 2.323994 \\
\hline Among Biodiesel fuels & 18.45735 & 2 & 9.228675 & 0.223342 & 0.800785 & 3.219942 \\
\hline Interaction & 19.11213 & 12 & 1.592678 & 0.038544 & 1 & 1.991013 \\
\hline Within & 1735.475 & 42 & 41.32082 & & & \\
\hline Total & 12344.96 & 62 & & & & \\
\hline
\end{tabular}

\section{Brake Specific Fuel Consumption (BSFC)}

In all tests the fuel consumption rates for biodiesels were higher than that of diesel fuel. Fig.(12) showed that the BSFC of the biodiesel fuels were higher than that of conventional diesel. This behavior is attributed to their noticeably lower heating value per unit mass, than that of the diesel fuel. Therefore, the amount of fuel introduced into the engine cylinder for a 
desired fuel energy input has to be greater with the biodiesel. The loss of heat value of biodiesels is compensated with higher fuel consumption to maintain the similar trend of power. The common BSFC trends of the tested biodiesels explain the absence of significant BSFC differences among biodiesel fuels as shown by their ANOVA in Table (13).

Table (13) Analysis of Engine Brake Specific Fuel Consumption variance - 1/kW.h

\begin{tabular}{|l|c|c|c|c|c|c|}
\hline Source of Variation & SS & df & MS & F & P-value & F crit \\
\hline Engine Speed Levels & 6.985354 & 6 & 1.164226 & 49.40728 & $1.83 \mathrm{E}-17$ & 2.323994 \\
\hline Among Biodiesel fuels & 0.001755 & 2 & 0.000877 & 0.037232 & 0.963484 & 3.219942 \\
\hline Interaction & 0.09193 & 12 & 0.007661 & 0.325108 & 0.980365 & 1.991013 \\
\hline Within & 0.989682 & 42 & 0.023564 & & & \\
\hline Total & 8.068721 & 62 & & & & \\
\hline
\end{tabular}

\section{AFR}

Fig.(13) shows the variation of AFR with engine speed. At test beginning, the tractor engine is set at full throttle position without any load, then the dynamometer is gradually started to exert loading on PTO shaft while engine is freely running at maximum rotation speed. At "No load" conditions, AFR values reached their maximum for all

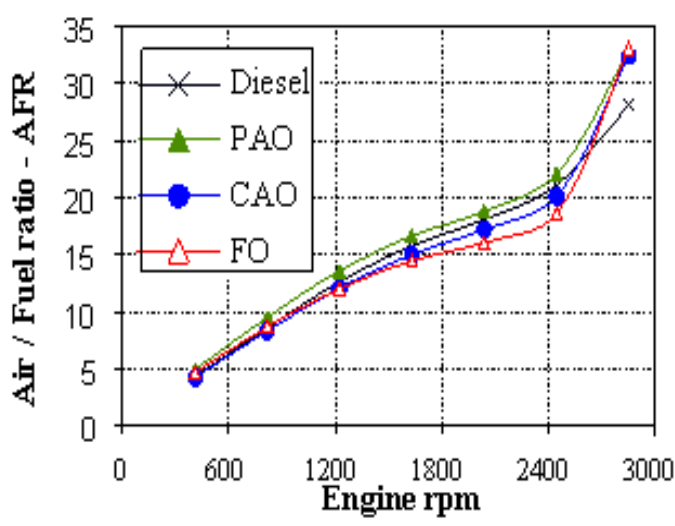

Fig.(13): Variation of AFR with engine speed.

tested fuels (28:1 - 33:1) despite the diminishing $\eta v$ in this stage; this can be referred to the little amount of fuel used under no load conditions; but they sharply decreased with load increase and corresponding fuel increase to reach 18:1 - 22:1. The ascended load caused more fuel consumption, and engine speed reduction to reach 2000 - $1500 \mathrm{rpm}$ where maximum BP \& BTE, minimum BSFC, are satisfied under maximum $\eta v$, and decreased AFR. The ascended load continuation leads to more of AFR decrease until reaching its minimum at full load conditions which almost braked engine speed due the braking effect of dynamometer loading, which in turn:

1) Reduced the amount of fuel used

2) Significantly reduced the air flow rate due to the sharp reduction in engine speed and the corresponding low $\eta v$ in this stage. 
Table (14) Analysis of Engine Air/ Fuel ratio variance - (kg air/kg fuel).

\begin{tabular}{|l|c|c|c|c|c|c|}
\hline Source of Variation & SS & df & MS & F & P-value & F crit \\
\hline Engine Speed Levels & 4449.307 & 6 & 741.5512 & 56.8229 & $1.41 \mathrm{E}-18$ & 2.323994 \\
\hline Among Biodiesel fuels & 28.98082 & 2 & 14.49041 & 1.110358 & 0.338918 & 3.219942 \\
\hline Interaction & 16.89678 & 12 & 1.408065 & 0.107896 & 0.999902 & 1.991013 \\
\hline Within & 548.1091 & 42 & 13.05022 & & & \\
\hline Total & 5043.294 & 62 & & & & \\
\hline
\end{tabular}

The AFR level of the conventional diesel along the whole engine speed range wasn't the highest as it usually was in the precedent engine performance characteristics. The biodiesel from palm oil was of the highest AFR. However the general behavior of AFR shown in this study for all tested fuels was corroborated by which was described by Gupta (2009). Mohammadi et al.(2012) pointed to that poor ratio of fuel to air (which is high AFR) was more visible at higher engine speeds, and increasing torque resulted in poor AFR, which also corroborate the present study results. The common AFR trends of the tested biodiesels explain the absence of significant AFR differences among biodiesel fuels as shown by their ANOVA in Table (14).

All checked biodiesels operational properties, didn't show any significant differences among biodiesels except for kinematic viscosity and pour point. Viscosity is a common distinctive property caused all biodiesels to be known as fuels of higher viscosity which results in poor atomization and larger fuel droplets followed by inadequate mixing of biodiesel droplets and air; higher viscosity and surface tension of biodiesels prevent their sufficient disintegration during injection process which may affect engine torque and $\mathrm{BP}$ especially at full-load conditions. CAO is of the highest viscosity with respect to which of FO \& PAO (Fig.(5)); their kinematic viscosity ANOVA showed significant differences between the tested Biodiesels; while each of them had the same common viscosity impact on engine performance characteristics; which is corroborated by the convergent trends of the tested biodiesels within each of the engine performance characteristics BP, BSFC, and AFR which none of them contained any significant differences between Biodiesels sources. Anyway CAO cannot be recommended as a vegetable oil source to produce biodiesel due to its upper viscosity. 
Similarly, ANOVA within pour point revealed significant differences among biodiesel fuels; while all of their engine performance characteristics BP, BSFC, and AFR didn't show any significant differences among biodiesel fuels; this could signify that pour point variance among biodiesels didn't affect their engine performance characteristics behavior. It could be noticed that the above related literature didn't identify a particular pour point difference which directly affect the engine performance characteristics behavior. So we may suppose that the pour point effect is implied within viscosity and participating its effect. Otherwise than kinematic viscosity, and pour point; the absence of the significant differences among biodiesels in the rest of their operational properties could be strongly the cause of the resulted convergence of the tested biodiesels trends which is confirmed by their unified behavior represented by BP, BSFC, and AFR as engine performance characteristics which in turn didn't show within each of them any significant differences between their Biodiesels Sources.

On the other hand, exhaust emissions are not related to biodiesel properties, they are mainly depending on the biodiesel chemical composition and combustion. ANOVA within $\mathbf{C O}$ emission indicated significant differences among biodiesel fuels; This case is already justified by Gumus et al. (2012) and Heywood (1988) that each biodiesel source may differ than another due to different factors effect as discussed in the above introduction.

Gomaa et al. (2014), reported that engine performance characteristics always showed the superiority of conventional diesel and the resemblance of the tested biodiesels trends. So, there is no any distinctive biodiesel source can be recommended among the three different tested fuels. The decision of selecting a specific biodiesel (from a specific source) depends mainly on its best economic feasibility wherever is used and on its BioSource availability. On the basis of the present study results, the previous decision could be applied at one condition that the selected biodiesel source should be neither of high viscosity, nor of high pour point in order to insure the correct selection of biodiesel source.

\section{CONCLUSION}

Three Biodiesel samples were extracted from three different and separate vegetable oils to determine their thermo-physical properties impact on 
engine performance characteristics and analyze their resulted exhaust emissions elements. The analysis of variance (ANOVA) was used to detect if any significant differences exist between these biodiesels of different individual sources. This statistical standard was applied to determine the probable significant differences presence or absence among biodiesel fuels in the resulted exhaust emissions and the thermophysical properties which affect engine performance characteristics. The judgement is based on the following principle: The absence of any significant differences among biodiesel fuels within any property can justify the resulting common graphical behavior among biodiesel fuels within any engine performance characteristic and vice versa.

After reviewing the whole results all checked biodiesels operational properties didn't show any significant differences among biodiesels except for kinematic viscosity and pour point. Despite the above discussed negative effect of both properties on biodiesel atomization and combustion, it didn't show any particular disturbance on the common graphical behavior among biodiesel fuels within each engine performance characteristics. This could be referred to the properties major common effect originated from their absence of any significant difference among biodiesel fuels. Similar behavior is recorded from all biodiesels exhaust emissions which didn't contain any significant differences among biodiesels except within CO emission. Finally, the decision of selecting the correct biodiesel source should depend mainly on its best economic feasibility wherever is used and on its Bio source availability, and should be neither of high viscosity, nor of high pour point.

\section{Nomenclature:}

FO: Fried oil biodiesel

CAO: Castor oil biodiesel

PAO: Palm oil biodiesel

$\mathrm{O}_{2}$ : Oxygen

$\mathrm{SO}_{2}$ : Sulfur dioxide

$\mathrm{CO}_{2}$ : Carbon dioxide

CO: Carbon monoxide

$\mathrm{NO}_{\mathrm{x}}$ : Nitrogen oxides

ppm: parts per million

BP: Brake Power
BTE: Brake thermal efficiency

VFC: Volumetric Fuel Consumption rate

BSFC: Brake Specific Fuel Consumption

BMEP: Brake Mean Effective Pressure

AFR: Air Fuel Ratio

$\mathrm{ml}$ : milli or $1 / 1000$.

$\mathrm{Pa}$ : Pascal $\left(\mathrm{N} / \mathrm{m}^{2}\right)$

$\mathrm{s}$ : second

$\mathrm{kg}$ : kilogram mass

$1:$ liter 


\section{REFERENCES}

- Aydin, H. and Ilk1lıc, C. 2010. Effect of ethanol blending with biodiesel on engine performance and exhaust emissions in a CI engine. Applied Thermal Engineering, 30: 1199-1204

- Buyukkaya, E., 2010 . "Effects of biodiesel on a DI diesel engine performance, emission and engine performance characteristics", Fuel, 89, pp. 3099-3105.

- Dwivedi G., M.P. Sharma and S. Jain. Impact of biodiesel and its blends with diesel and methanol on engine performance, Int. J. Energy Sci. 2011, 1, 105-109.

- Fernando, S.; P. Karra; R. Hernandez, and S. K. Jha,2007 . Effect of incompletely converted soybean oil on biodiesel quality. Energy;32(5):844-851.

- Gomaa, A.E., H. H. Mohamed, A. A. El Gwady, and M. D. AlAseebee, 2014. Evaluation of tractor diesel engine performance using biodiesel from three different individual sources. Misr J. Ag. Eng. Vol.31 - No.(2). 403-424.

- Gumus M, Sayin C, Canakci M. 2012. The impact of fuel injection pressure on the exhaust emissions of a direct injection diesel engine fueled with biodiesel-diesel fuel blends. Fuel ; 95:486-94.

- Gupta, H.N., 2009. Fundamental of Internal Engine performance Engines. , ISBN-978-81-203-2854-2859

- Heywood J. 1988. Internal engine performance engine fundamentals. McGraw-Hill.

- Kumar P., M.P. Sharma, and G. Dwivedi, 2014. Impact of biodiesel on engine performance, performance and exhaust emissions of diesel engines. Journal of Integrated Science \& Technology, 2(2) 57-63.

- Mohammadi, P.; A. M. Nikbakht, M. Tabatabaei, and K. Farhadi, 2012 Experimental investigation of performance and emission characteristics of DI. Energy, 46 , 596-605.

- Peng, D., (2015). Exhaust emission characteristics of various types of biodiesels. Advances in Mechanical Engineering, Vol. 7(7) 1-7.

- Rehman, A., R. K. Pandey, S. Dixit, and R. M. Sarviya, 2009. Performance and emission evaluation of diesel engine fueled with vegetable oil. International Journal of Environmental Research, Vol. 3, No. 3, pp. 463-470. 
- Shrestha, D.S., J. Van Gerpen, J. Thompson, and A. Zawadzki, 2005. Cold flow properties of biodiesel and effect of commercial additives. An ASAE Meeting Presentation Paper Number: 056121.Written for presentation at the 2005 ASAE Annual International Meeting Sponsored by ASAE. Tampa, Florida17 - 20 July 2005.

- Sonune P. P., and H. S. Farkade 2012. Performance and Emissions of CI Engine Fuelled With Preheated Vegetable Oil and Its Blends A Review. International Journal of Engineering and Innovative Technology (IJEIT) Vol. 2, Issue 3.

\section{الملخص العربي}

\section{انبعاثات العادم للايزل الحيوي وخواصه المؤثرة على خصائص أداء المحرك}

ا.د/ احمد السيد علي جمعه'، د/ هيثم حسين يوسف محمد ؟و م/ مناف ذياب فندي العصيب

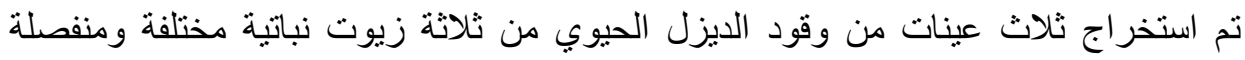

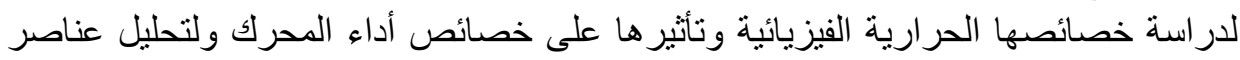

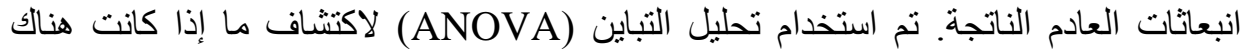

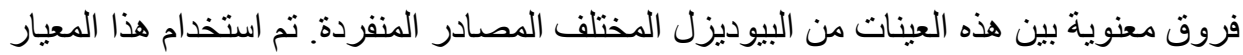

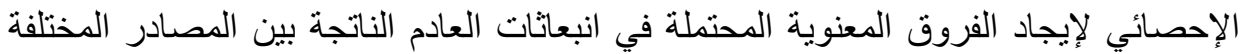

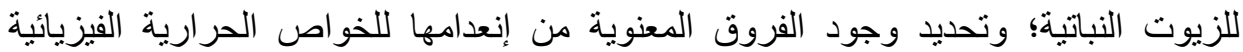

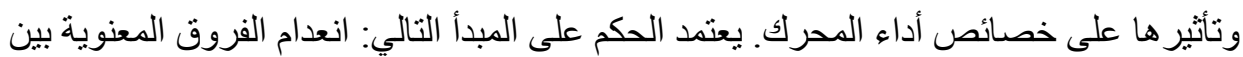

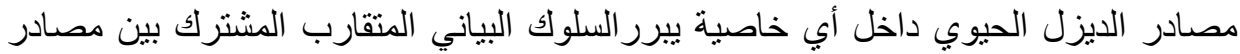

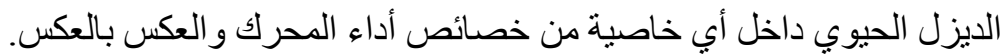

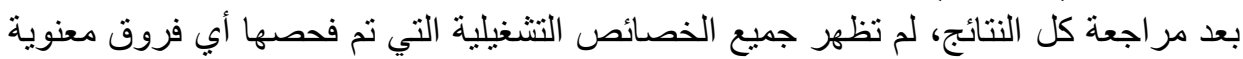
بين عينات البيوديزل المختلف المصادر باستثناء اللزوجة الحركية ونقطة الإنسكاب. وعلى الئى

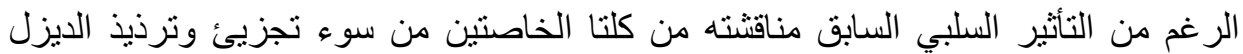

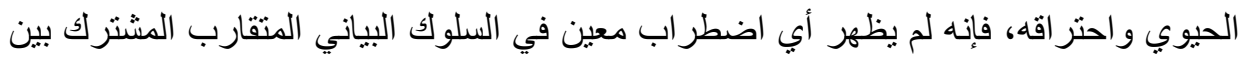

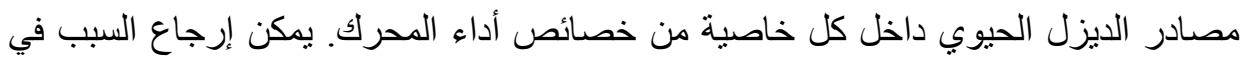

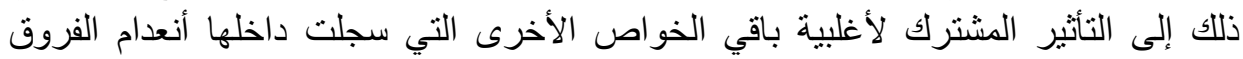

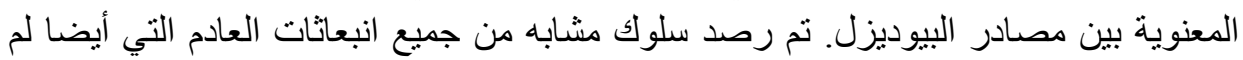

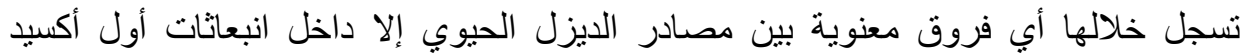

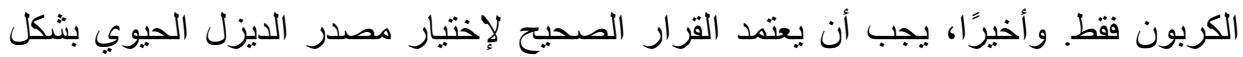

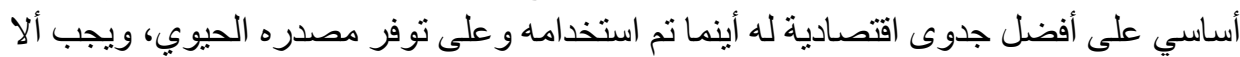

$$
\text { يكون ذو لزوجة مرتفعة أو ذو نقطة إنسكاب مرتفعة. }
$$

1 ـ أستاذ الهندسة الزراعية المتفرغ - كلية الزراعة، سابا باشا - جامعة الإسكندرية - ج.م.ع.

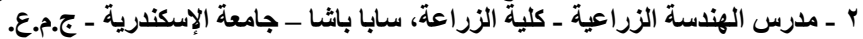

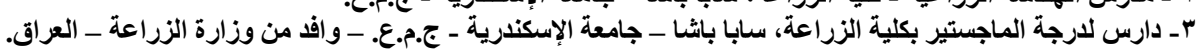

